\title{
PENGARUH TINGKAT PENDIDIKAN DAN SERTIFIKASI GURU TERHADAP KINERJA GURU \\ (Studi kasus SD di Kecamatan Parungpanjang Kabupaten Bogor)
}

\author{
Lia Asmalah S.Pd,.MM \\ Dosen Fakultas Ekonomi Universitas Pamulang \\ Email : asmalahlia63@gmail.com
}

\begin{abstract}
ABSTRAK
Penelitian ini berjudul "Pengaruh Tingkat Pendidikan dan Sertifikasi terhadap Kinerja Guru Pada Guru Sekolah Dasar di Parung panjang". Penelitian ini bertujuan untuk mengetahui pengaruh Tingkat Pendidikan dan Sertifikasi terhadap kinerja gutu baik secara parsial dan simultan dengan menggunakan metode penelitian deskriftif kuantitatif. Responden dalam penelitian ini adalah guru sekolah dasar yang berada di Parung panjang yang berjumlah 118 responden.

Hasil penelitian ini dapat disimpulkan sebagai berikut: (1) Terdapat pengaruh yang positif dan signifikan antara Tingkat Pendidikan dengan kinerja guru dengan nilai $t_{\text {hitung }} 3,308>\mathrm{t}$ tabel 0,1658 . Nilai koefisien regresi parsial sebesar 0,280 atau $28 \%$ dan nilai signifikansi 0,001 , hal ini berarti lebih besar dari taraf kepercayaan yang telah ditetapkan sebesar 0,05 (5\%). (2) Terdapat pengaruh yang positif dan signifikan antara Sertifikasi dengan kinerja guru dengan nilai $t_{\text {hitung }}$ sebesar 3,062> $t_{\text {tabel }} 1,658$. Nilai koefisien regresi parsial sebesar 0,236 atau 23,6\% dan nilai signifikansi 0,001 , hal ini berarti lebih besar dari taraf kepercayaan yang telah ditetapkan sebesar 0,05 (5\%). (3) Terdapat pengaruh yang positif dan signifikan antara Tingkat Pendidikan dan Sertifikasi dengan kinerja guru dengan nilai $F_{\text {hitung }} 15,474>F_{\text {tabel }}$ 3,08 . Nilai koefisien regresi secara simultan sebesar 0,212 atau $21,2 \%$ sedangkan sisanya sebesar 78,8\% dijelaskan oleh variabel lain diluar variabel penelitian ini.

Penelitian ini menyimpulkan bahwa kinerja guru sekolah dasar di Parung panjang di pengaruhi oleh Tingkat Pendidikan dan Sertifikasi.
\end{abstract}

\section{Kata Kunci : Tingkat Pendidikan, Sertifikasi dan Kinerja Guru}


PENDAHULUAN

\section{A. Latar Belakang}

Pendidikan merupakan hal yang sangat penting untuk menjamin perkembangan dan kelangsungan kehidupan suatu bangsa.Pendidikan adalah usaha sadar untuk menyiapkan peserta didik melalui kegiatan bimbingan, pengajaran dan atau latihan bagi peranannya dimasa yang akan datang. Setiap warga negara Indonesia berhak memperoleh pendidikan pada tahap manapun dalam perjalanan hidupnya. Pendidikan dapat diperoleh baik melalui jalur pendidikan sekolah maupun jalur pendidikan luar sekolah. Peningkatan dan pemerataan pendidikan merupakan salah satu aspek pembangunan yang mendapat prioritas utama dari Pemerintah Indonesia. Sistem Pendidikan Nasional yang sekarang berlaku diatur melalui Undang-Undang Pendidikan Nasional.

Kelemahan para pendidik kita, mereka tidak pernah menggali masalah dan potensi para siswa.Pendidikanidealnya memperhatikan kebutuhan anak bukan malah memaksakan sesuatu yang membuat anak kurang nyaman dalam menuntut ilmu. Proses pendidikan yang baik adalah dengan memberikan kesempatan pada anak untuk kreatif. Itu harus dilakukan sebab pada dasarnya gaya berfikir anak tidak bisa dipaksakan.

Berdasarkan survey United Nations Educational, Scientific and Cultural Organization (UNESCO), terhadap kualitas pendidikan di negara-negara berkembang di Asia Pacific, Indonesia menempati peringkat 10 dari 14 negara.Sedangkan untuk kualitas para guru, kulitasnya berada pada level 14 dari 14 negara berkembang. Salah satu faktor rendahnya kualitas pendidikan di Indonesia adalah karena lemahnya para guru dalam menggali potensi anak.Para pendidik seringkali memaksakan kehendaknya tanpa pernah memperhatikan kebutuhan, minat dan bakat yang dimiliki siswanya.
Hasil penelitian United Nation Development Programe (UNDP) pada tahun 2007 tentang Indeks Pengembangan Manusia menyatakan Indonesia berada pada peringkat ke-107 dari 177 negara yang diteliti. Peringkat Indonesia yang rendah dalam kualitas sumber daya manusia ini adalah gambaran mutu pendidikan Indonesia yang rendah. Salah satu penyebab rendahnya mutu pendidikan di Indonesia adalah komponen mutu guru. Rendahnya profesionalitas guru di Indonesia dapat dilihat dari kelayakan guru mengajar.

Pengembangan sektor pendidikan sejak semula memang diarahkan untuk menjadi tanggung jawab bersama antara orang tua, masyarakat dan Pemerintah. Ki Hajar Dewantara bahkan pernah menegaskan tanggung jawab tersebut dengan istilah "Tri Pusat Pendidikan", orang tua, masyarakat dan pemerintah dituntut untuk saling bekerja sama mengantarkan anak didik mencapai kedewasaannya. Pendekatan ini dapat dilaksanakan dengan People Centered Development yang dapat mengubah peran masyarakat dari penerima pasif pelayan pemerintah yang bertujuan untuk memenuhi kebutuhan pokok menjadi anggota masyarakat yang mampu berperan serta aktif kedalam pembangunan.

Keberhasilan proses pendidikan dalam rangka menghasilkan sumber daya manusia Indonesia yang berkualitas, akan ditentukan oleh banyak faktor antara lain, peserta didik, tenaga pendidik, kurikulum, manajemen pendidikan dan fasilitas pendidikan. Disamping itu lingkungan juga akan sangat berpengaruh untuk mendukung keberhasilan proses pendidikan, terutama keluarga, masyarakat, pemerintah dan swasta (dunia usaha dan dunia industri).

Lembaga pendidikan formal atau sekolah sebagai suatu organisasi kerja diselenggarakan secara sengaja, sistematik dan terarah. Sebagai organisasi kerja, setiap personal, sarana dan programnya 
harus dikendalikan guna menciptakan proses atau serangkaian kegiatan yang terarah pada tujuan tertentu untuk menghasilkan lulusan yang berkualitas.Untuk mewujudkan hal tersebut, telah dilakukan langkah-langkah strategis misalnya: penyempurnaan kurikukulum, mengadakan analisis yang lebih seksama terhadap tujuan-tujuan pendidikan, pengembangan dibidang sarana seperti perbaikan gedung, pengadaan peralatan praktek, pengadaan buku, penyediaan biaya operasional, peningkatan kemampuan profesional guru melalui berbagai penataran.

Berbagai langkah untuk peningkatan guru semakin marak namun masih banyak guru belum memiliki profesionalisme yang memadai untuk menjalankan tugasnya sebagaimana disebut dalam pasal 39 UU No 20/2003 yaitu merencanakan pembelajaran, melaksanakan pembelajaran, menilai hasil pembelajaran, melakukan pembimbingan, melakukan pelatihan, melakukan penelitian dan melakukan pengabdian masyarakat.

Kendati secara kuantitas jumlah guru di Indonesia cukup memadai, namun secara kualitas mutu guru di negara ini, pada umumnya masih rendah. Secara umum, para guru di Indonesia kurang bisa memerankan fungsinya dengan optimal, karena pemerintah masih kurang memperhatikan mereka, khususnya dalam upaya meningkatkan profesionalismenya. Secara kuantitatif, sebenarnya jumlah guru di Indonesia relatif tidak terlalu buruk. Apabila dilihat ratio guru dengan siswa, angka-angkanya cukup bagus yakni di SD 1:22, SLTP 1:16, dan SMU/SMK 1:12. Meskipun demikian, dalam hal distribusi guru ternyata banyak mengandung kelemahan yakni pada satu sisi ada daerah atau sekolah yang kelebihan jumlah guru, dan di sisi lain ada daerah atau sekolah yang kekurangan guru. Dalam banyak kasus, ada SD yang jumlah gurunya hanya tiga hingga empat orang, sehingga mereka harus mengajar kelas secara paralel dan simultan.

Pada sektor pendidikan, pengembangan sumber daya manusia tidak dapat dilepaskan dari upaya untuk meningkatkan kemampuan guru terhadap peningkatan pengembangan pengetahuannya dalam proses belajar mengajar. Fungsi pengembangan ini memusatkan perhatian pada peningkatan kemampuan dan motivasi dari para guru untuk melaksanakan pekerjaannya. Hal ini berdasarkan pada undang-undang nomor 20 tahun 2003 tentang sistem pendidikan nasional,bahwa guru (pendidik) merupakan tenaga profesional yang bertuhas merencanakan dan melaksanakan proses pembelajaran, menilai hasil pembelajaran, melakukan pembimbingan dan pelatihan.

Tingkat pendidikan merupakan hal penting dalam dunia akademis atau pendidikan, tingkat pendidikan seorang pendidik hendaknya sesuai dengan peraturan yang berlaku, berdasarkan observasi dilapangan masih banyak gurugur yang memiliki tingkat pendidikan dikategorikan rendah, hal ini kurang baik karena seorang pendidik di tuntut untuk mengembangkan serta mengamalkan ilmu yang dimiliki, masih banyak tingkat pendidikan yang belum sesuai kriteria pendidik.

Sertifikasi guru adalah proses pemberian sertifikat pendidik kepada guru. Sertifikat pendidik diberikan kepada guru yang telah memenuhi standar profesional guru. Guru profesional merupakan syarat mutlak untuk menciptakan sistem dan praktik pendidikan yang berkualitas. Namun hasil observasi di lapangan sertifikasi guru belum menjamin guru tersebut professional dalam bekerja, hal ini terlihat dari keseharian yang dilakukan oleh guru sertifikasi yang idealnya memberikan contoh yang baik kepada guru yang belum sertifikasi atau yang masih honorer, hal ini menyebabkan dampak yang kurang baik serta guru sertifikasi 
yang jumlahnya masih sedikit juga menjadi kendala profesionalisme guru.

Berdasarkan observasi peneliti di lapangan bahwa permasalahan kinerja yaitu masalah semangat kerja guru, semangat kerja guru masih belum bisa dikatakan baik karena masih seringnya guru datang terlambat ke sekolah, seringnya keluar masuk ruangan saat kegiatan belajar mengajar berlangsung hal ini sangat disayangkan karena hendaknya pelayanan kepada siswa bisa lebih optimal. Kerjasama menjadi hal yang baik apabila dapat bekerja secara bersama-sama dalam menyelesaikan suatu tugas atau kegiatan namun permasalahan yang terjadi adalah para karyawan saling mengandalkan kepada salah seorang, atau orang-orang tertentu saja, akhirnya kerjasama tidak berjalan efektif, padahal banyak tugas atau kegiatan yang sulit dilaksanakan tanpa adanya kerjasama, hal ini juga menjadi permasalahan penting bagi sekolah.

Jabatan guru merupakan salah satu jabatan profesionalisme, menurut Supriyadi Dedi bahwa :"Profesional menunjuk pada suatu pekerjaan atau jabatan yang menuntut keahlian, tanggung jawab dan kesetiaan profesi. Suatu profesi secara teori tidak dapat dilakukan oleh sembarang orang yang tidak dilatih atau dipersiapkan untuk itu." (Supriyadi Dedi, 2008:32) Banyak guru yang tidak menghargai profesinya, apalagi berusaha mengembangkan profesi tersebut. Perasaan rendah diri karena menjadi guru, menyalah gunakan profesi untuk kepuasan dan kepentingan diri, ketidak mampuan guru melaksanakan tugas profesinya. Komersialisasi mengajar dan lain-lain sering menyebabkan pudarnya wibawa guru, sehingga pengakuan profesi guru semakin merosot. Itu sebabnya pengakuan dan usaha menegakkan profesi guru harus dimulai dari guru itu sendiri. Usaha yang dapat dilakukan harus dimulai dengan mengakui secara sadar makna profesi itu, mengakui dan mencintai tugas profesi serta berusaha mengembangkan profesi yang disandang.
Pendidik tidak boleh merasa puas dengan apa yang telah dimilikinya. Tantangan-tantangan selalu menghadang didepan mata,pada beberapa tahun yang silam pendidik di SD hanya cukup dengan berijazah SPG dan yang sederajat. Namun kenyataannya, sudah tidak dapat terelakkan sebagai konsekuensi dari arus inovasi dan modernisasi global yang juga melanda dunia pendidikan kita, Guru-guru SD agar dapat mengimbangi perkembangan yang terjadi dewasa ini, minimal harus setara dengan S-1. Hal ini tidak menutup kemungkinan dalam tiga atau lima tahun mendatang harus berkualifikasi S-2.

Di samping tuntutan persyaratan tingkat pendidikan diatas, supaya tugastugas guru semakin mantap dan informasiinformasi baru, metode-metode mengajar baru dapat cepat diterima oleh guru, setiap guru harus mengikuti pengembangan atau pelatihan/penataran. Melalui pelatihanpelatihan, guru diharapkan memperoleh penyegaran-penyegaran peningkatan efisiensi dan efektifitas kerja.Di dalam menekuni bidangnya guru selalu bertambah pengalamannya. Semakin bertambah masa kerjanya diharapkan guru semakin banyak pengalamanpengalamannya. Pengalaman-pengalaman ini erat kaitannya dengan peningkatan profesionalisme pekerjaan. Guru yang sudah lama mengabdi di dunia pendidikan harus lebih profesional dibandingkan guru yang beberapa tahun mengabdi.

Ada lebih dari 20 Sekolah Dasar di wilayah Kecamatan Parungpanjang dengan kondisi guru yang cukup beragam, baik dari latar belakang dan jenjang pendidikan, golongan, tugas, jabatan yang diemban maupun yang sudah tersertifikasi sesuai kemampuan. Kondisi beragam tersebut sudah sesuai dengan kompetensi yang mereka miliki masing-masing.di Kecamatan Parungpanjang yang beragam sangat mempengaruhi guru dalam kinerjanya, sehingga terdapat guru yang sudah bersertifikat, baik itu PNS maupun guru honorer. Kondisi ini yang mendorong 
penulis untuk melakukan penelitian Berjudul"Pengaruh Tingkat Pendidikan, dan Sertifikasi Guru terhadap Kinerja Guru (Studi Kasus pada Sekolah DasarDi Kecamatan Parungpanjang)".

\section{B. Identifikasi Masalah}

Berdasarkan latar belakang di atas maka dapat diidentifikasikan beberapa masalah sebagai berikut:

1. Tingkat pendidikan guru rendah.

2. Tingkat pendidikan guru belum sesuai kriteria.

3. Tuntutan profesionalisme guru belum dilakukan oleh semua guru.

4. Guru sertifikasi masih sedikit.

5. Kinerja guru sertifikasi belum optimal.

6. Kesadaran untuk meningkatkan profesionalisme guru belum maksimal.

\section{Pembatasan Masalah}

Sesungguhnya banyak masalah yang dapat diangkat kepermukaan dalam penelitian ini, namun penulis perlu membatasi masalah yang lebih terperinci dan jelas agar pemecahannya terarah dan berhasil. Jadi tulisan ini hanya dibatasi pada masalah tingkat pendidikan, sertifikasi guruserta pengaruhnya terhadap kinerja guru pada guru-guru yang tersertifikasi di SD di Kecamatan Parungpanjang.

\section{Tinjauan Pustaka}

Teori yang mendasari didalam pembahasan penelitian tesis ini adalah teori yang benar-benar mempunyai hubungan dengan permasalahan yang dibahas. Sebagai landasan dalam pembahasan penelitian ini, dikemukakan teori tentang manajemen, manajemen sumberdaya manusia, kinerja guru, tingkat pendidikan dan sertifikasi guru. Teori tersebut diantaranya sebagai berikut:

\section{Manajemen}

Istilah manajemen berasal dari kata management (Bahasa Inggris), berasal dari kata "to manage" yang artinya mengurus atau tata laksana. Sehingga manajemen dapat diartikan bagaimana cara mengatur, membimbing dan memimpin semua orang yang menjadi bawahannya agar usaha yang sedang dikerjakan dapat mencapai tujuan yang telah ditetapkan sebelumnya. Menurut Richard Daft (2004:8) manajemen adalah pencapaian sasaran-sasaran organisasi dengan cara yang efektif dan efisien melalui perencanaan pengorganisasian, kepemimpinan dan pengendalian sumberdaya organisasi. Menurut Oe Liang Lee dalam Marihot Manullang (2004:2) menyatakan bahwa manajemen adalah seni dan ilmu perencanaan, pengorganisasian, pengarahan, pengkoordinasian, dan pengontrolan "human and natural resources" terutama human resources untuk mencapai tujuan yang telah ditentukan terlebih dahulu.

T. Hani Handoko (2008:10) mendefinisikan manajemen merupakan bekerja dengan orang-orang untuk menentukan, menginterpretasikan dan mencapai tujuan-tujuan organisasi dengan pelaksanaan fungsi-fungsi perencanaan, pengorganisasian, penyusunan personalia, pengarahan, kepemimpinan dan pengawasan. Dapat dikatakan bahwa manajemen adalah suatu proses dengan proses mana pelaksanaan suatu tujuan tertentu diselenggarakan dan di awasi. Manajemen dalam arti singular (tunggal) disebut manajer. Menurut Nurul Oktima (2012:183), manajemen adalah ilmu dan seni dalam perencanaan, pengorganisasian, pelaksanaan dan pengawasan, penyusunan sumberdaya manusia untuk mencapai tujuan yang telah ditetapkan. Menurut Riva'i, Veizhal (2010:15) Manajer ialah pejabat yang bertanggung jawab atas terselenggaranya aktivitasaktivitas manajemen agar tujuan unit 
yang di pimpinnya tercapai dengan menggunakan bantuan orang lain.

\section{a.Fungsi Manajemen}

Fungsi- fungsi manajemen menurut Luther Gullick :

1. Fore Casting, adalah kegiatan meramalkan, memproyeksikan, atau mengadakan taksiran terhadap berbagai kemungkinan yang akan terjadi sebelum suatu rencana yang lebih pasti dapat dilakukan. Misalnya suatu akademi, meramalkan jumlah mahasiswa yang akan melamar belajar di akademi tersebut. Ramalan tersebut dengan menggunakan beberapa indikator-indikator.

2. Planning termasuk budgeting. Perencanaan ialah penentuan serangkaian tindakan untuk mencapai suatu hasil yang diinginkan.

3. $\begin{array}{lr}\quad \text { Organizing } & \text { atau } \\ \text { pengorganisasian, } & \text { adalah } \\ \text { keseluruhan } & \text { aktivitas } \\ \text { manajemen } & \text { dalam }\end{array}$ mengelompokkan orang-orang serta penetapan tugas, fungsi, wewenang, serta tanggung jawab masing-masing dengan tujuan terciptanya aktivitasaktivitas yang berdaya guna dan berhasil guna dalam mencapai tujuan yang jelas ditentukan terlebih dahulu.

4. Staffing atau Asembling Resources, merupakan salah satu fungsi manajemen berupa penyusunan personalia pada sesuatu organisasi sejak dari merekrut tenaga kerja, pengembangannya sampai dengan usaha agar setiap petugas memberi daya guna maksimal kepada organisasi.

5. Directing atau Commanding, ialah berfungsi untuk mengkoordinasi kegiatan berbagai unsur organisasi agar dapat efektif tertuju kepada realisasi tujuan yang ditetapkan sebelumnya.

6. Leading, pekerjaan leading meliputi 5 macam kegiatan, yakni

- Mengambil keputusan,

- Mengadakan komunikasi agar ada bahasa yang sama antara manajer dan bawahan,

- Memberi semangat inspirasi dan dorongan kepada bawahan supaya mereka bertindak,

- Memilih orang-orang menjadi anggota kelompoknya, serta

- Memperbaiki pengetahuan dan sikap-sikap bawahan agar mereka terampil dalam usaha memcapai tujuan yang telah ditetapkan.

7. Coordinating, yakni berfungsi untuk melakukan berbagai kegiatan agar tidak terjadi kekacauan, percekcokan, kekosongan kegiatan, dengan jalan menghubung-hubungkan, menyatu-padukan dan menyelaraskan pekerjaanpekerjaan bawahan sehingga terdapat kerjasama yang terarah dalam usaha mencapai tujuan bersama / tujuan organisasi.

8. Motivating (pendorongan kegiatan), fungsinya berupa pemberian inspirasi, penyemangat, dan dorongan kepada bawahan, agar bawahan 
melakukan kegiatan secara sukarela sesuai apa yang dikehendaki oleh atasan tersebut.

9. Controlling, yaitu berfungsi mengadakan penilaian dan sekaligus bila perlu mengadakan koreksi sebagai apa saja yang sedang dilakukan bawahan dapat di arahkan kejalan yang benar dengan maksud tercapai tujuan yang sudah di gariskan semula.

10. Reporting atau pelaporan, merupakan salah satu dari fungsi manajemen berupa penyampaian perkembangan atau hasil kegiatan atau pemberian keterangan mengenai segala hal yang berkaitan dengan tugas dan fungsi-fungsi kepada pejabat yang lebih tinggi baik secara lisan maupun tulisan sehingga yang menerima laporan dapat memperoleh gambaran tentang pelaksanaan tugas orang yang memberi laporan.

\section{b. Tingkatan Manajemen}

Teoritikus manajemen, Robert N. Anthony memberikan nama untuk tiga pembagian tingkat manajemen utama, yaitu puncak, utama dan rendah. Para manajer di puncak hierarki organisasi, seperti presiden dan wakil presiden seringkali disebut berada pada tingkat perencanaan strategis (strategic planning level), mengakui adanya fakta bahwa keputusan mereka seringkali akan memiliki dampak pada keseluruhan organisasi selama bertahun-tahun kemudian.

Henry

Mintzberg mengemukakan Manajer tingkat menengah meliputi manajer regional, direktur produk dan kepala divisi. Pada tingkatan ini disebut tingkat kendali manajemen (management control level). Hal ini dikarenakan manajer tingkat menengah memiliki tanggung jawab untuk menjalankan rencana dan memastikan tercapainya tujuan. Manajemen tingkat ini disebut juga manajemen tingkat taktis. Manajer tingkat rendah meliputi kepala departemen, penyelia dan pimpinan proyek. Tingkat terendah ini disebut tingkat kendali operasional (Operational control level).

\section{Manajemen Sumberdaya Manusia}

Manajemen sumberdaya manusia mengandung arti pengakuan terhadap pentingnya peran manusia pada organisasi sebagai sumberdaya yang vital dalam pencapaian tujuantujuan organisasi, pemanfaatan berbagai fungsi dan kegiatan personalia untuk menjamin bahwa mereka digunakan secara efektif dan efisien agar dapat bermanfaat bagi individu, organisasi/perusahaan dan masyarakat menurut Notoatmojo (1992:5)

Menurut Hasibuan (2005:10) Manajemen sumberdaya manusia merupakan bagian dari ilmu manajemen yang memfokuskan perhatiannya pada pengaturan peran sumberdaya manusia dalam kegiatannya suatu organisasi.

Unsur man (manusia) ini berkembang menjadi suatu bidang ilmu manajemen yang disebut Manajemen Sumberdaya Manusia yang merupakan terjemahan dari man power management. Manajemen yang mengatur unsur manusia ini ada yang menyebutnya manajemen kepegawaian atau manajemen personalia (Personnel Management).

Menurut Tulus (1992) Dalam Suharyantno dan Hadna (2006 : 13) Manajemen sumberdaya manusia merupakan suatu bidang manajemen 
yang khusus mempelajari hubungan dan peranan manusia dalam organisasi perusahaan.Unsur manajemen sumberdaya manusia adalah manusia yang merupakan tenaga kerja pada perusahaan atau organisasi.

$$
\text { Pengertian manajemen }
$$

sumberdaya manusia menurut Gary Dessler (2005:5) yang mengatakan bahwa: "manajemen sumberdaya manusia merupakan kebijakan dan praktek menentukan aspek manusia atau sumberdaya manusia dalam posisi manajemen, termasuk merekrut, menyaring, melatih, memberi penghargaan dan penilaian".

$$
\text { Manajemen Sumberdaya }
$$

manusia adalah bagian dari manajemen.Oleh karena itu, teori-teori manajemen umum menjadi dasar pembahasannya.

Menurut Mangkunegara (2002:2) Manajemen sumberdaya manusia memfokuskan pembahasannya mengenai pengaturan peranan manusia dalam mewujudkan tujuan yang optimal. Pengaturan itu meliputi masalah perencanaan (human resources planning). Pengorganisasian, pemeliharaan, kedisiplinan dan pemberhentian tenaga kerja untuk membantu terwujudnya tujuan perusahaan, karyawan dan masyarakat. Jelasnya manajemen sumberdaya manusia mengatur tenaga kerja manusia sedemikian rupa sehingga terwujud tujuan perusahaan, kepuasaan karyawan dan masyarakat.

$$
\text { Manajemen sumber daya }
$$

manusia yang merupakan man power management, ada yang menyebutkan manajemen kepegawaian atau manajemen personalia. Edwin Flippo dalam bukunya "Personnel Management" mengatakan manajemen personal adalah perencanaan, pengorganisasian, pengarahan dan pengendalian dari pengadaan, pengembangan, kompensasi, pengintegrasian, pemiliharaan, individu, karyawan, dan masyarakat.
Manajemen

sumberdaya manusia menurut Veithzal Riva'i (2009:1) merupakan salah satu didang dari manajemen umum yang meliputis segi - segi perencanaan, pengorganisasian, pelaksanaan dan pengendalian. Proses ini terdapat dalam fungsi/bidang produksi, pemasaran, keuangan maupun kepegawaian.

Manajemen sumberdaya manusia menurut Malayu S.P Hasibuan (2006:10) yang menyatakan bahwa "Manajemen sumberdaya manusia adalah ilmu dan seni mengatur hubungan dan peranan tenaga kerja agar efektif dan efisien membantu terwujudnya tujuan perusahaan, karyawan dan masyarakat". Manajemen sumberdaya manusia (human resources management) adalah proses memperoleh, melatih, menilai dan memberikan kompensasi pada karyawan memperhatikan hubungan kerja mereka, kesehatan, keamanan dan masalah keadilan.

Manajemen sumberdaya manusia pada hakikatnya adalah penerapan manajemen tersebut khusus untuk sumberdaya manusia sehinnga dapat didefinisikan manajemen sumberdaya manusia adalah seni untuk merencanakan, mengorganisasikan, mengarahkan, mengawasi kegiatankegiatan sumber daya manusia atau karyawan dalam rangaka mencapai tujuan organisasi.

Soekidjo Notoatmodjo
$(2009: 86)$ menyatakan bahwa manajemen sumberdaya manusia atau manajemen personalia adalah suatu pengakuan terhadap pentingnya sumberdaya manusia atau tenaga kerja dalam organisasi dan pemanfaatannya dalam berbagai fungsi dan kegiatan untuk mencapai tujuan organisasi. Manajemen sumberdaya manusia diperlukan untuk meningkatkan daya guna dan hasil guna sumberdaya manusia dalam organisasi, dengan 
memberikan kepada organisasi suatu satuan kerja yang efektif.

Ditengah suasana persaingan yang kian tajam peran sumberdaya manusia akan semakin terasa, semua aktifitas manajemen sumberdaya manusia di perlukan untuk membantu perusahaan untuk mencapai suatu tujuan.

Berdasarkan teori diatas penulis menyimpulkan bahwa manajemen sumberdaya manusia adalah ilmu bagian dari manajemen yang mengatur tenaga kerja agar berfungsi efisien dan efektif sehingga mampu menjalankan tugas organisasi untuk mencapai tujuan yang diharapkan.

\section{A. Tempat dan Waktu Penelitian}

enulis

Dalammelakukanpenelitianinip

akanmengambilobjekpenelitiandi

seluruh Sekolah Dasar Negeri maupun

swasta yang berada diKecamatan

Parungpanjang kabupaten

Bogor.Pelaksanaan penelitian

dilakukan mulai bulan September

2015 sampai dengan Desember 2015.

\section{B. Metodologi penelitian}

Metode penelitian adalah suatu cara prosedur ataucara untuk mengetahui sesuatu, yang mempunyai langkah - langkah sistematis. Penelitian pada umumnya bertujuan untuk mengetahui dan menemukan sesuatu yang baru tentang suatu masalah atau fenomena yang terjadi pada suatu objek.

Dalam melakukan penelitian dilakukan langkah - langkah yang tersusun dan sistematis untuk mendapatkan dataset hingga tujuan peneliti dapat tercapai. Menurut Sugiono (2008:4),"'Metode penelitian adalah cara ilmiah untuk mendapatkan data yang valid dengan tujuan yang dapat ditemukan, dibuktikan dan dikembangkan sebagai suatu pengetahuan sehingga pada gilirannya dapat digunakan untuk memahami, memecahkan dan mengantisipasi masalah".

Penelitian ini dirancang

dengan metode deskriptif dengan pendekatan kuantitatif.Metode kuantitatif deskriptif adalah digunakan untuk menjelaskan fenomenal yang terjadi perihal data penelitian. Sedangkan metode kuantitatif digunakan untuk menjelaskan pengaruh variable bebas terhadap variable terikat pada penelitian ini. Sedangkan jenis penelitian ini adalah korelasional yaitu penelitian yang menghubungkan antara dua variable atau lebih.

Menurut Saifudin Azwar (2004: 8) penelitian korelasional bertujuan untuk menyelidiki sejauh mana variasi pada suatu variable bekaitan dengan variasi pada satu atau lebih variable lain berdasarkan koefisien korelasi.

\section{C . Hasil Penelitian}

\section{Deskripsi Objek Penelitian}

Responden yang dijadikan objek penelitian adalah sampel seluruh Guru Sekolah Dasar di Parungpanjang yang berjumlah 118 guru. Dikarenakan jika menggunakan populasi secara keseluruhan terlalu banyak maka peneliti menggunakan metode sampel dari populasi $167 \mathrm{di}$ ambil sampel 118 sampel sebagai responden.

\section{Karakteristik Responden}

a. Responden Menurut Jenis Kelamin

Perbedaan jenis
kelamin dapat menjadi pembeda bagi seseorang dalam kinerjanya, Karena responden disini adalah seluruh Guru Sekolah Dasar di Parungpanjang yang terdiri dari manajemen, tenaga pendidik maupun tenaga kependidikan. Dalam kuisioner 
yang saya sebarkan kepada responden, berikut ini adalah komposisi yang didapat menurut jenis kelamin, sebagai berikut:

Tabel 4.1

Jumlah Responden Menurut Jenis Kelamin

\begin{tabular}{|c|c|c|}
\hline $\begin{array}{c}\text { Jenis } \\
\text { Kelamin }\end{array}$ & Jumlah & Prosentase \\
\hline Laki-laki & 50 & $42 \%$ \\
\hline Perempuan & 68 & $48 \%$ \\
\hline Total & $\mathbf{1 1 8}$ & $\mathbf{1 0 0 \%}$ \\
\hline
\end{tabular}

Sumber: UPTP Parungpanjang

Berdasarkan tabel diatas dapat diketahui bahwa responder terbanyak adalah laki-laki yaitu sebanyak 50 orang (42\%) sedangkan perempuan 68 orang (48\%). Hal ini menunjukan bahwa laki-laki dalam kinerja dominan dalam bekerja di Sekolah Dasar kecamatan Parungpanjang.

\section{b. Responden Menurut Usia}

Perbedaan kondisi individu seperti usia seringkali dapat memberikan perbedaan dalam kinerjanya. Ini dilakukan mengetahui dan juga untuk mengelompokan usia dari Guru Sekolah Dasar kecamatan Parungpanjang. Rincian pengelompokan usia responden dapat dilihat pada tabel berikut ini, yaitu:

Tabel 4.2

Jumlah Responden Menurut Usia

\begin{tabular}{|c|c|c|}
\hline Usia & Jumlah & Persentase \\
\hline $18-25$ tahun & 35 & 29,6 \\
\hline $26-35$ tahun & 22 & 18,7 \\
\hline $36-45$ tahun & 38 & 32,3 \\
\hline $45-55$ tahun & 19 & 16,1 \\
\hline $\begin{array}{c}>55 \\
\text { tahun }\end{array}$ & 4 & 3,3 \\
\hline Total & $\mathbf{1 1 8}$ & $\mathbf{1 0 0 \%}$ \\
\hline
\end{tabular}

Sumber: UPTP Parungpanjang
Berdasarkan tabel diatas dapat diketahui bahwa untuk usia responden yang terbanyak adalah berusia antara 36-45 tahun sebanyak 38 orang atau $32,3 \%$. Diikuti dengan usia antara 18-25 tahun sebanyak 35 orang atau 29,6\%, rentang usia 26-35 tahun sebanyak 22 orang atau $18,7 \%$, rentang usia 45-55 tahun sebanyak 19 orang atau $16,1 \%$ dan yang terakhir rentang usia $>55$ tahun sebanyak 4 orang atau 3,3\%. Dapat disimpulkan bahwa rata-rata pegawai yang menjadi responden adalah pegawai usia muda dan produktif.

c. Responden Menurut Tingkat Pendidikan

Tingkat pendidikan juga dapat menunjukan status sosial yang mempengaruhi orang dalam jabatan dan kinerjanya. Komposisi responden menurut tingkat pendidikannya dapat dilihat pada table

Tabel 4.3

Jumlah Responden Menurut Tingkat Pendidikan Terakhir

\begin{tabular}{|c|c|c|}
\hline Jenjang & Jumlah & Prosentase \\
\hline SMA & 33 & $28 \%$ \\
\hline S1 & 78 & $66 \%$ \\
\hline S2 & 7 & $6 \%$ \\
\hline Total & $\mathbf{1 1 8}$ & $\mathbf{1 0 0 \%}$ \\
\hline
\end{tabular}

Sumber: UPTPParungpanjang

\section{A. Kesimpulan}

Penelitian ini dilakukan pada Guru Sekolah Dasar di Parungpanjang yang menguji mengenai pengaruh tingkat pendidikan dan sertifikasi terhadap kinerja guru. Berdasarkan hasil analisis dari pembahasan maka dapat diambil kesimpulan sebagai berikut : 
1. Tingkat pendidikan berpengaruh positif dan signifikan terhadap kinerja guru Sekolah Dasar di Kecamatan Parungpanjang, Bogor sebesar $28 \%$.

2. Sertifikasi berpengaruh positif dan signifikan terhadap kinerja guru Sekolah Dasar di Kecamatan Parungpanjang, Bogorsebesar $23,6 \%$.

3. Tingkat pendidikan dan sertifikasi secara simultan berpengaruh positif dan signifikan terhadap kinerja guru Sekolah Dasar di Kecamatan Parungpanjang, Bogorsebesar 21,2\% Selebihnya dipengaruhi oleh variabel atau faktor lain diluar penelitian ini.

\section{B. Saran}

Berdasarkan hasil analisis dan kesimpulan penelitian, maka ada beberapa saran sebagai berikut:

1. Untuk variabel tingkat pendidikan masih cukup banyak responden menjawab tidak setuju 13 responden $(11,02 \%)$ dan kurang setuju 42 responden $(35,59 \%)$ dari butir instrument nomor 13 yang berindikator pendidikan lanjutan, para guru harus memperhatikan pendidikan lanjutan dewan guru agar mampu meningkatkan kualitas dalam mengajar dan memiliki guru kompetensi sesuai dengan harapan dengan adanya pendidikan lanjutan baik ke tingkat sarjana maupun pascasarjana dan diharapkan mampu adanya bantuan dalam program pemerintah mengenai pendidikan lanjutan guru dengan pemberian beasiswa atau program peningkatan mutu guru.

2. Untuk variabel sertfikasi masih cukup banyak responden menjawab kurang setuju 45 responden $(38,14 \%)$ dari butir instrument nomor 14 yang berindikator pengalaman organisasi, sebaiknya pihak gugus memberikan pengarahan ke guru-guru untuk aktif dalam organisasi, missal bergabung dengan PGRI, Guru sebaiknya memiliki pengalaman organisasi untuk meningkatkan kemampuan guru dalam wawasan mengajar serta kemampuan berorganisasi dalam sekolah.

3. Untuk variabel kinerja guru masih cukup banyak responden menjawab tidak setuju 4 responden $(3,39 \%)$ dan yang kurang setuju 13 responden $(11,02 \%)$ dari butir instrument nomor 5 yang berindikator pengetahuan tentang pekerjaan, sebaiknya pihak gugus mampu memberikan pengarahan tentang apa yang harus dikerjakan oleh guru, Karena tugas guru bukan saja hanya mengajar tetapi harus merapihkan data administrasi mengajar seperti pembuatan program tahunan, program semester, silabus dan RPP, perlu adanya diklat agar guru mampu mengajar sesuai dengan seharusnya

\section{DAFTAR PUSTAKA}

Chatab, Nevizond. Diagnostic Management, cetakan kesatu. Penerbit: PT Serambi Ilmu Semesta, Jakarta, 2007.

Daft, Richard. Manajemen edisi 5. Penerbit: PT Gramedia Pustaka Pertama, Jakarta, 2004.

Dessler, Garry. Manajemen Sumberdaya Manusia, edisi kesepuluh. Penerbit: PT. Indeks, Jakarta, 2006. 
Feryanto, Agung, Dkk. Materi Ekonomi Volume 3 "Spesialisasi dan Pembagian kerja". Penerbit: Cempaka Putih, Klaten, 2013.

Guritno, Bambang Manajemen Personalia.PT Gramedia Pustaka Utama, Jakarta, 2006.

Handoko, Hani T. Manajemen, edisi kedua. Penerbit: BPFE, Yogyakarta, 2006.

Hasibuan, Malayu. Manajemen Sumberdaya Manusia. Penerbit: PT Bumi Aksara, Jakarta, 2005.

Idris, Pendidikan Indonesia. Penerbit: PT Ragrafindo Persada, Jakarta, 2007.

Irianto, Manajemen Pendidikan. Penerbit: PT Ragrafindo Persada, Jakarta, 2005.

Ismail, Hanif. Balance scorecard. Penerbit: PT Gramedia Pustaka Utama, Jakarta, 2009.

Mangkunegara, Prabu. Manajemen Sumber Daya Manusia dan Personalia. Penerbit: CV Alfa Beta, Bandung, 2005.

Manajemen Pendidikan.Penerbit: CV Alfa Beta, Bandung, 2005.

Manullang, Marihot. Manajemen Sumber Daya Manusia. Penerbit: P.T Bumi Aksara, Jakarta, 2004.

Mulyasa, Manajemen Organisasi Pendidikan.Penerbit: PT. Mitra Wacana Media, Jakarta, 2007.

Nawawi, Hadari,Perencanaan SDM untuk Organisasi yang Kompetitif.Penerbit: Gadjah Mada University Press, Yogyakarta, 2004.
Notoadmojo, Soekidjo. Pengembangan Sumberdaya Manusia. Penerbit: Rineka Cipta, Jakarta, 2010.

Oktima, Nurul. Kamus Ekonomi. Penerbit: Aksarra Sinergi Media, Surakarta, 2012.

Pangabean, Mutiara. Manajemen Kinerja. Penerbit: PT Ragrafindo Persada, Jakarta, 2005.

Personal Management, terjemahan oleh Agus Darma, Penerbit: Erlangga, Jakarta, 2004.

Riva'i, Veizhal. Manajemen Sumberdaya Manusia untuk Perusahaan. Penerbit: PT Ragrafindo Persada, Jakarta, 2009.

Siagian, Dergibson. Metode Statistika. Penerbit: PT Gramedia Pustaka Utama, Jakarta, 2006.

Siagian, Sondang P. Manajemen Sumberdaya Manusia. Penerbit: Salemba empat, Jakarta, 2006.

Simamora, Hendri. Pengembangan Manajemen Sumber Daya Manusia. Salemba empat, Jakarta, 2004.

Soedarmayanti,Dinamika Pendidikan Nasional. Penerbit: PT Gramedia Pustaka Utama, Jakarta, 2006.

Sugiyono, Metode Penelitian Kuantitatif Kualitatif $R \& D$. Penerbit: CV Alfa Beta, Bandung, 2011.

Sumanjuntak, Reksu J. Pengantar ekonomi SDM. Penerbit: FEUI, Jakarta, 2003.

Suparmoko. Metode Penelitian Praktis. Penerbit: BPFE: Yogyakarta, 2007.

Suranta, Manajemen Sumber Daya Manusia. Penerbit:CV Alfa Beta, Bandung, 2005 
Surhayanto dan Hadna. Manajemen

Sumber Daya Manusia. Penerbit:

Mitra Wacana Media, Jakarta, 2005.

Zakiyudin, Ais. Sistem Informasi

Manajemen. Penerbit: PT. Mitra Wacana

Media, Jakarta, 2011. 